\title{
Role of Canal Lining on Groundwater Fluctuations: A Modeling Simulation Approach for Jaalwala Distributary, Bahawalnagar
}

\author{
Muhammad Hammad Atique Khan1, Muhammad Usman Saleem², Sajid Rashid Ahmad2, \\ Nasir Ahmad1, Shahid Jamil Sameeni', Muhammad Akram³, Muhammad Farooq ${ }^{3}$ \\ ${ }^{1}$ Institute of Geology, University of the Punjab, Lahore, Pakistan \\ ${ }^{2}$ Collage of Earth and Environmental Sciences, University of the Punjab, Lahore, Pakistan \\ ${ }^{3}$ Irrigation Department, Government of Pakistan, Lahore, Pakistan \\ Email: osman.geomatics@gmail.com
}

How to cite this paper: Khan, M.H.A., Saleem, M.U., Ahmad, S.R., Ahmad, N., Sameeni, S.J., Akram, M. and Farooq, M. (2017) Role of Canal Lining on Groundwater Fluctuations: A Modeling Simulation Approach for Jaalwala Distributary, Bahawalnagar. Open Journal of Applied Sciences, 7, 213-232.

https://doi.org/10.4236/ojapps.2017.75019

Received: January 2, 2017

Accepted: May 28, 2017

Published: May 31, 2017

Copyright $\odot 2017$ by authors and Scientific Research Publishing Inc. This work is licensed under the Creative Commons Attribution International License (CC BY 4.0).

http://creativecommons.org/licenses/by/4.0/

\begin{abstract}
Jaalwala Distributary was selected to see the consequences of concrete lining on the underlying saline groundwater table. Its middle and tail portions were concrete lined whereas the head portion was still unlined. Visual MODFLOW 2011.1 was used to simulate the effects of concrete lining on saline groundwater in two-dimensional format. Simulation results showed a gradual rise of electrical conductivity (EC) up to $7000 \mu \mathrm{S} / \mathrm{cm}$ and decline in water table depth to nine feet $(2.74 \mathrm{~m})$. It observed negligible inflows from the distributary through its western boundary due to formation of a permanent barrier in the way of seepage of any kind. Results have further predicted that freshwater layer available beneath the Jaalwala Distributary (before its lining) will finish ultimately and the below present saline water also move upward to take this vacated place. Hence it was concluded to line the canals of saline water areas from their sides which will not only protect them from erosion but canal water theft as well.
\end{abstract}

\section{Keywords}

Water Balance, Jaalwala Distributary, Saline Water Intrusion,

Hydrostatic Pressure and Interface

\section{Introduction}

Dependency of our lives on water cannot be overlooked. It not only exists on the surface of the earth in so many forms but is also present below the lithosphere, having linkages with each other [1]. Apart from natural activities, groundwater was also restored artificially by surplus irrigation, seepage from man-built water 
ways, and water applied intentionally to supplement it [2]. All the ancient empires were established near or along some perpetual water sources [3]. The total quantity of water on earth remains the same though it changes from one form to another. It exists as liquid at room temperature, in gaseous state above its boiling point and as solid in the form of snow, hail or ice subject to the temperature, pressure and elevation of that place [4]. Good quality of water found on surface or beneath this earth collectively constitute to the freshwater resources of this planet [5].

Canals were human-made channels used for conveying water to irrigate fields and gardens which navigate on a small or large scale. The history of excavation of canals goes back to at least three thousand years as can be traced in the footprints of Nineveh and Babul civilizations. Theory of flow of fluids was put forward by Torricelli in 1643. It was the Kennedy who excavated a canal in the Indo-Pak Subcontinent (in the late 19th century) which carried silt-ridden water in it [6]. These canals were designed in such a way that the silt flowing in these channels were unable to damage their sides, wear down their banks or clog them by being dropped in their middle thus jeopardizing their operations [7].

In order to safeguard a canal against any physical damage streamline its gradient offers resistance against infiltration and transport the allocated amount of water to reach its ends. Canal lining has an addition advantage in strengthening the banks of canals, checking the growth of weeds and algae in them and lessening the seepage losses that caused in the earthen channels [8]. Seepage of water from the earthen structure of Bari Doab Canal in India was taken as an engineering failure when it started operation in 1859. Many suggestions to curtail this outflow from the earthen boundaries of this canal were put forward but the most popular and feasible approach was to line this canal altogether with concrete. This was adopted as it minimized the incidents of breaches in the canal structure and acquisition of additional valuable agricultural land was not involved thereby a saving to the government exchequer [9] [10].

The main purpose behind lining of various main canals, distributaries and minors in Pakistan is to reduce seepage losses from the initially excavated earthen canals along with improving their hydraulic performance, reduction in their operation costs, stoppage of canal-water theft, and delivery of freshwater right into the field of the farmers [11].

Materials used for lining the canals must be of sufficient strength and quality to resist the pressure caused by the flowing water. It also prevents seepage from canal sides and bed so that the hydraulic structure remains safeguarded [12]. Different materials like bricks, cement or concrete were used for lining the canals in Pakistan. These constituents have their own capacities: reduce the quantity of seepage from their surfaces, decrease the eroding capacity of canal banks from its water, minimize the chances of breach from the high discharged water, allow minimal weeds growth along their sides and minimize the cost of their maintenance [6] (Table 1).

The main source of recharge in the Indus Plain was infiltration from the upper 
Table 1. Impact of different lining materials used for reducing the rate of seepage [6].

\begin{tabular}{ccc}
\hline Types of lining material & $\begin{array}{c}\text { Initial rate of } \\
\text { seepage }\end{array}$ & $\begin{array}{c}\text { Stabilized rate of } \\
\text { seepage }\end{array}$ \\
\cline { 2 - 3 } No Material (Earthen/ Unlined) & Cusecs per million square foot \\
Cement, Lime and Brick Ballast (1:5:12) & 22.4 & 10.26 \\
Cement and Sand (1:3) Mortar sandwiched & 1.05 & 0.125 \\
between the two & 0.507 & 0.027 \\
4" thick Concrete, Sand and Brick Ballast (1:1:3) & 0.367 & 0.02 \\
4" thick Concrete, Lime, Brick Ballast (5:12:24) & 1.223 & 0.39 \\
\hline
\end{tabular}

land surface where it is either permeable and has ruptures or flaws. After the development of canal irrigation in this region the rate of percolation increased manifolds from these porous surfaces thus making the water come up within a few feet from the land [13]. Apart from the acts of nature aquifers of the Indus Valley River System (IVRS) were restored artificially by activities like surplus irrigation, seepage from waterways and water applied intentionally to supplement them [2] [14]. Seepage from unlined channels not only helps recharge the aquifers of the Indus Valley but also was a source of clean and fresh water for all the dwellers living along such waterways [15].

Before the excavation of canals in the IVRS water table of various aquifers was quite deep that enjoyed a dynamic balance of inflows and outflows of percolated water into them. This was disturbed with the addition of a constant source of seeped fresh water from the earthen canals making the water of canal irrigated areas rise at an average rate of $1.5 \mathrm{ft}$. per year thereby making these areas waterlogged by the late 1930 (Table 1). When this standing water in the fields subsided because of evaporation and less reclamation supplies from the canals the land was left with a covered surface of accumulated salts. It was believed that these salts came up to the ground surface along with the rising groundwater until research during 1937 revealed that they were present in the soil which mixed with the upcoming groundwater and were left on the ground with the subsidence of this water [7].

Salts present in the shallow groundwater zones of the Indus plain moved towards the surface and got deposited there because of high evaporation and less rainfall. This process was augmented by poor drainage of freshwater which failed to exert enough pressure from the upper side on this up scaling saline water and stop its vertical movement towards the ground surface [16]. This rise of groundwater in the saline water-logged areas not only harmed the quality of soil but also diminished the quantity of yields with an additional disadvantage of damaging the civil structures around it. Deposition of huge mounds of salts along the water channels in the saline water areas are due to primary salinity whereas secondary salinity in an area is the outcome of inordinate agricultural practices prevalent in the local population [17]. 
Canals in Pakistan were excavated as earthen (unlined) channels which not only reduce the cost of these projects but have an additional benefit of recharging the groundwater with its freshwater outflows. In areas having freshwater aquifers seepage from the flowing canals was accepted by the underlying aquifer as such and they become part of it however in the saline water zones such seeped freshwater from the earthen channels is not assimilated in these saline water aquifers but remain above their upper surface as an independent entity. This layers of seeped freshwater presses the saline water (Table 1) downwards because of difference in their densities and hydrostatic pressure. This layer of freshwater was not only used by the community for its domestic purposes but is taken by animals and plants besides irrigating the farm fields. However, lining these canals hinder the seepage and recharge of groundwater resulting either in lowering of fresh water or rise of saline water from below. These results in disturbance of water balance of that area forcing the farmers to use both canal and underground water to cater for their needs [8] [14].

A lens of fresh water was formed below the running unlined canal and above the underlying saline aquifer which has a distinct interface formed as a result of variance in their gravities. The width of this freshwater layer formed below the operational earthen canals decrease with their distance away from these channels (Table 1) in small oceanic islands where the thickness of fresh water layer floating above the salty seawater decrease towards the coast [2] [14]

Like all other countries distribution of freshwater was not even in Pakistan. It was surplus in some places while scanty at others. There was also plenty of water available in some seasons whereas it is rare in others. The gap between demand and supply of water as a result of rise in population was more than ten percent in the beginning of this century (2000) which is likely to go up to three times by 2025 due to non-construction of new reservoirs and hence non-replenishment of groundwater [4]. Per capita availability of water in 1951 was more than five thousand cubic meters which has dwindled to thirteen hundred cubic meters [18].

This groundwater study aims to develop a simulated flow model for the canal command area (CCA) of Jaalwala Distributary located at Bahawalnagar, Pakistan in a two-dimensional format. It will focus on the reasons behind shrinking and completely diminishing of freshwater layer below the Jaalwala Distributary. Details regarding rise of saline water to the natural surface level (NSL) and fluctuations being taking place in the dimensions of the freshwater layer present below the Jaalwala Distributary before and after its concrete lining.

In the following sections study area, methods and methodology, results with conclusion will explained.

\section{Study Area}

In order to compare the pros and cons of concrete lining of canals in the salinewater zone Jaalwala Distributary in district Bahawalnagar province of Punjab Pakistan was selected. Bahawalnagar district $\left(73.40345^{\circ} \mathrm{E}, 29.97473^{\circ} \mathrm{N}\right)$ was in 
the Lower Indus Plain (LIP) which mainly dry and arid having very warm summers and cold winters with scanty rainfall. Jaalwala Distributary is an offshoot of Eastern Sadiqia Canal originating from its RD: $219+500 / \mathrm{R}$ (reduce distance number 219 plus 500 feet and $1 \mathrm{RD}=1000 \mathrm{ft}$ ). It has a length of $29 \mathrm{~km}$ with an authorized full supply discharge of 112 Cusecs operating on perennial basis depending on the availability of water. The total lined portion covers a length from RD: $407+220$ to $947+430$ (tail) whereas the head reach from RD: $0+000$ to $407+219$ is still unlined (Figure 1).

Total number of outlets (Mogas) in this distributary was 67 out of which 54 are located in the Jaalwala Distributary whereas the remaining 13 outlets are present at Jaalwala Minor. Water coming out of these outlets of the distributary goes into the watercourses owned by the agriculture department from where this water is distributed to the fields. Some watercourses in the command of Jaalwala Distributary were lined whereas the others are not. Major crops of the study area were wheat and cotton which are grown in Rabiand Kharif seasons respectively. Climate of the study area is arid and mean annual rainfall in the area remains near to $119.4 \mathrm{~mm}$ while temperature varies from highest value of $52^{\circ} \mathrm{C}$ during

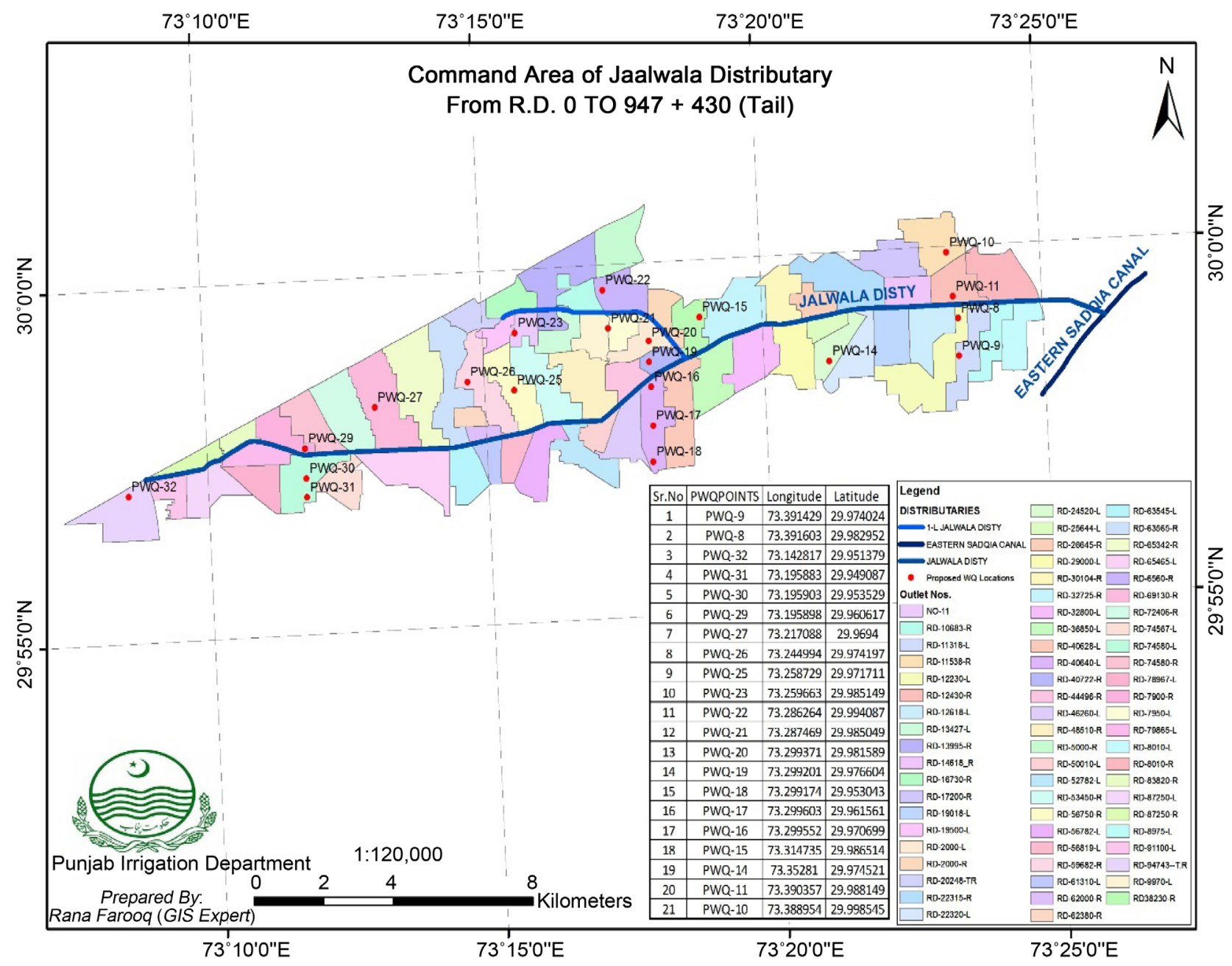

Figure 1. Map of Jaalwala Distributary Canal Command Area (CCA) along with24 Water Quality Points (PWQs). 
summers and touches its lowest of $6.3^{\circ} \mathrm{C}$ in winters.

The understudy area lies to the south-east of river Sutlej in the IVRS which has thick alluvium of Quaternary Age. The top 300 feet of land was of alluvium nature having major portion of unconsolidated sand ranging from very fine to coarse grains with clay particles of varying width lying in between them. Traces of lime are also seen at certain depths which are of fluvial and Aeolian origin. The area consists of active as well as abandoned flood plains of Ghaghara River. Strong winds action in the area results in shifting of dunes from one place to another resulting in undulating landforms at regional level.

The alluvium deposit in the area of Jaalwala Distributary contains a groundwater reservoir with water depth varying from three to twelve feet below the land surface. The physical characteristics of the predominant sandy aquifer shows some heterogeneity in terms of both lateral and vertical parameters but when speak in broader terms, this aquifer behaves as a single contiguous, unconfined aquifer in the top 300 feet of this alluvial section. Most groundwater stored in this alluvial aquifer is saline though a layer of freshwater overlying this saline aquifer exists beneath and along the periphery of Jaalwala Distributary. The fresh-saline water interface formed between this fresh seeped water and the saline groundwater lies generally at shallow depths from where this freshwater layer is tapped by means of limited yield wells to avoid quality deterioration through up coning.

Electrical conductivity was recorded from twenty-one selected sites show that it is highly saline with respect to irrigation parameters though small pockets of freshwater is present. There were various sections where more seepage takes place due to the fact that the canal bed in those areas is earthen and has not been concrete lined. The depth situation of water in the command of Jaalwala Distributary was as followed: 3 to 12 feet at the head section, 4 to 8 feet in the middle region and 3 to 11 feet in the tail. Thus the overall average depth of the entire reach of Jaalwala Distributary comes out to be 6.8 feet which is equivalent to about 2.0 meters (Table 2).

Out of 535 Tube-Wells (TWs) installed in the Canal Command Area (CCA) of this distributary 100 were located at the head, 215 in the middle whereas 220 at the tail end section. Their average density comes out to be 2.5 tube wells/100 acres having their discharge ranging from 0.42 to 0.5 cusecs. The tube wells installed along or near the Jaalwala Distributary vary in depth from $10.7 \mathrm{~m}-17.7$ $\mathrm{m}$ having an average bore depth of 14.3 meters. Twenty-seven (27) points were selected along Jaalwala Distributary for measuring the water table depths of the area (Figure 2 and Table 3 ).

Table 2. Water table depth situation in Jaalwala Distributary command area.

\begin{tabular}{ccccc}
\hline Sr. No. & Reach & $\begin{array}{c}\text { Minimum } \\
\text { (in feet) }\end{array}$ & $\begin{array}{c}\text { Maximum } \\
\text { (in feet) }\end{array}$ & $\begin{array}{c}\text { Average } \\
\text { (in feet) }\end{array}$ \\
\hline 1. & Head & 3.33 & 12.17 & 7.2 \\
2. & Middle & 4.08 & 8 & 5.98 \\
3. & Tail & 3.17 & 11 & 7.46 \\
\hline
\end{tabular}


Table 3. Watercourse wise bore depth and location of tube wells in the vicinity of Jaalwala Distributary.

\begin{tabular}{|c|c|c|c|}
\hline \multirow{2}{*}{ Sr. No. } & \multicolumn{2}{|c|}{ No. of Tube Wells as per Outlet Nos. } & \multirow{2}{*}{$\begin{array}{l}\text { Bore Depths } \\
\quad \text { (in feet) }\end{array}$} \\
\hline & No. of Tube Wells & Outlet Nos. & \\
\hline 1. & 6 & $8+010 R$ & 63 \\
\hline 2. & 7 & $8+010 \mathrm{~L}$ & 62 \\
\hline 3. & 5 & $8+975 \mathrm{~L}$ & 65 \\
\hline 4. & 5 & $11+318 \mathrm{~L}$ & 64 \\
\hline 5. & 4 & $12+230 \mathrm{~L}$ & 61 \\
\hline 6. & 2 & $12+430 \mathrm{R}$ & 60 \\
\hline 7. & 5 & $11+538 \mathrm{R}$ & 61 \\
\hline 8. & 1 & $17+200 \mathrm{R}$ & 59 \\
\hline 9. & 1 & $14+618 \mathrm{R}$ & 57 \\
\hline 10. & 1 & $12+618 \mathrm{~L}$ & 54 \\
\hline 11. & 1 & $19+018 \mathrm{~L}$ & 55 \\
\hline 12. & 16 & $22+315 \mathrm{R}$ & 56 \\
\hline 13. & 2 & $22+320 \mathrm{~L}$ & 48 \\
\hline 14. & 4 & $24+520 \mathrm{~L}$ & 50 \\
\hline 15. & 4 & $25+644 \mathrm{~L}$ & 56 \\
\hline 16. & 10 & $25+645 \mathrm{R}$ & 56 \\
\hline 17. & 15 & $29+000 \mathrm{~L}$ & 47 \\
\hline 18. & 11 & $30+104 \mathrm{R}$ & 53 \\
\hline 19. & 16 & $32+800 \mathrm{~L}$ & 49 \\
\hline 20. & 22 & $32+725 \mathrm{R}$ & 50 \\
\hline 21. & 11 & $36+850 \mathrm{~L}$ & 54 \\
\hline 22. & 13 & $38+230 \mathrm{R}$ & 53 \\
\hline 23. & 15 & $40+628 \mathrm{~L}$ & 40 \\
\hline 24. & 2 & $40+640 \mathrm{~L}$ & 40 \\
\hline 25. & 10 & $40+722 \mathrm{R}$ & 50 \\
\hline 26. & 15 & $44+496 \mathrm{R}$ & 50 \\
\hline 27. & 9 & $46+260 \mathrm{~L}$ & 45 \\
\hline 28. & 19 & $48+510 R$ & 42 \\
\hline 29. & 8 & $50+010 \mathrm{~L}$ & 42 \\
\hline 30. & 5 & $52+790 \mathrm{~L}$ & 40 \\
\hline 31. & 9 & $53+450 \mathrm{R}$ & 42 \\
\hline 32. & 10 & $56+750 \mathrm{R}$ & 47 \\
\hline 33. & 16 & $56+782 \mathrm{~L}$ & 50 \\
\hline 34. & 14 & $56+819 \mathrm{~L}$ & 45 \\
\hline 35. & 13 & $61+310 \mathrm{~L}$ & 40 \\
\hline 36. & 8 & $59+682 \mathrm{R}$ & 42 \\
\hline
\end{tabular}




\section{Continued}

\begin{tabular}{llll}
\hline 37. & 12 & $62+380 \mathrm{R}$ & 40 \\
38. & 18 & $63+565 \mathrm{~L}$ & 40 \\
39. & 13 & $63+565 \mathrm{R}$ & 42 \\
40. & 10 & $65+342 \mathrm{R}$ & 40 \\
41. & 27 & $65+465 \mathrm{~L}$ & 40 \\
42. & 19 & $69+130 \mathrm{R}$ & 45 \\
43. & 17 & $72+406 \mathrm{R}$ & 40 \\
44. & 8 & $74+567 \mathrm{~L}$ & 45 \\
45. & 21 & $74+580 \mathrm{R}$ & 55 \\
46. & 8 & $74+580 \mathrm{~L}$ & 45 \\
47. & 9 & $78+967 \mathrm{~L}$ & 35 \\
48. & 14 & $79+865 \mathrm{~L}$ & 45 \\
49. & 13 & $79+30 \mathrm{R}$ & 40 \\
50. & 10 & $83+820 \mathrm{R}$ & 40 \\
51. & 8 & $87+250 \mathrm{R}$ & 40 \\
52. & 4 & $87+250 \mathrm{~L}$ & 35 \\
53. & 5 & $91+100 \mathrm{~L}$ & 55 \\
54. & 4 & $94+743 \mathrm{TR}$ & 50 \\
\hline 0. & & & \\
\hline & 1 & & 45 \\
\hline
\end{tabular}

Total No. of Tube wells $=535$.

\section{Methods and Methodology}

Samples were taken twice a year for Pre-Monsoon and Post-Monsoon periods of 2009-2012. The electrical conductivity and $\mathrm{pH}$ of these samples were recorded on the spot with the help of Hanna HI 9812 pH-EC-TDS meter. It can also make recommendations regarding relief measures to be taken for restoring the understudy system, quantify the amount of water coming in and going out of it, categorize the pumping sites present in it and compute the amount of water being recharged into this system [19].

A groundwater model was prepared to compare the amount of groundwater leached during unlined and lined conditions respectively using MODFLOW in association with other digitized computer based techniques like Geographical Information Systems (GIS) and SURFER while the pace in decline of quality of groundwater was investigated using analytical techniques.

The model encompasses an area of nearly $370 \mathrm{~km}^{2}$ with horizontal and vertical dimensions. The model grid was designed to provide adequate spatial resolution within the study area in order to simulate response of the aquifer with respect to unlined and lined distributaries. The domain of the model has been extended to a considerable distance from the boundary of command area to minimize impacts of exterior boundary conditions on the model solution (Figure 3).

The model domain has been discredited into 50 rows and 185 columns in 


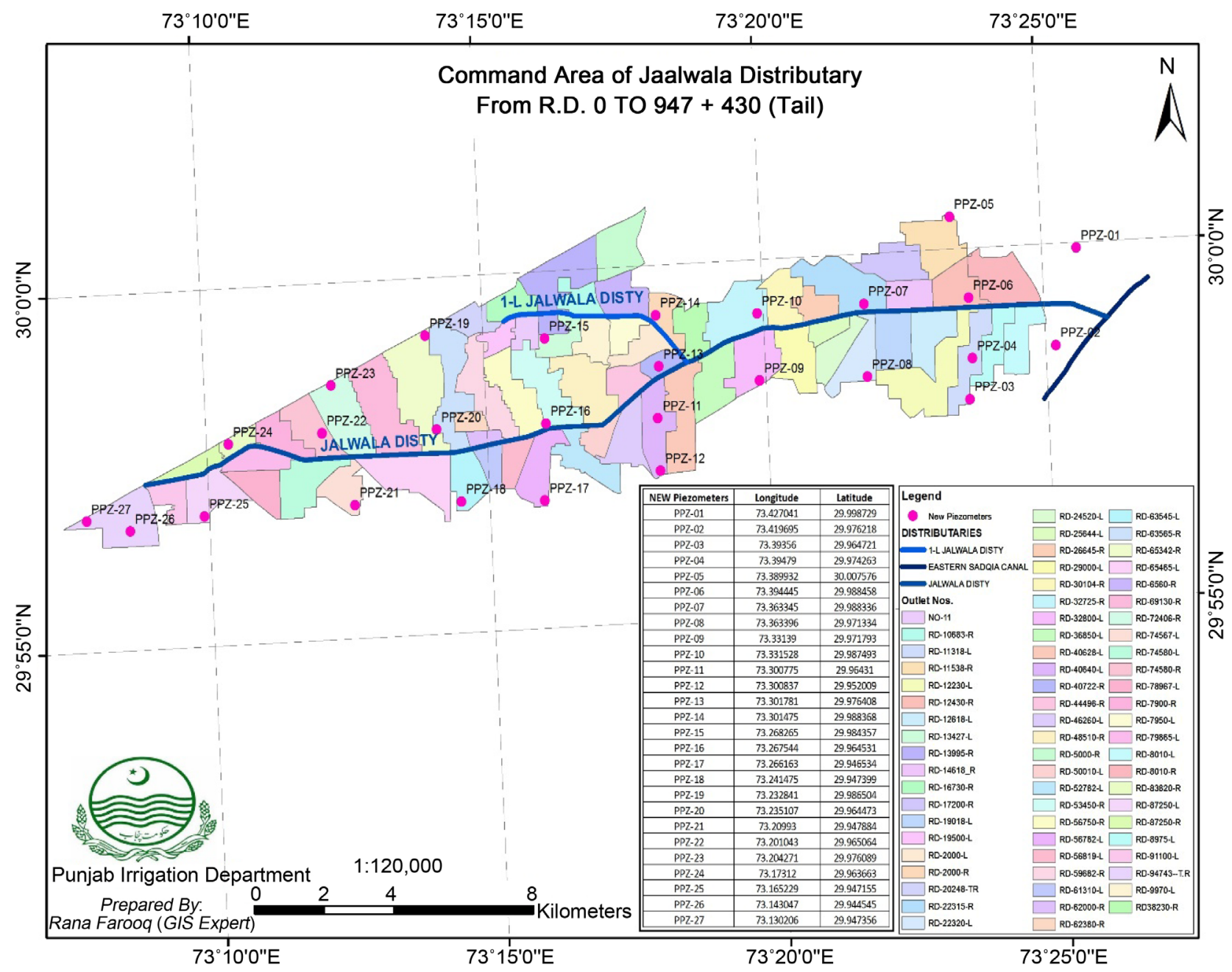

Figure 2. Map of twenty-seven (27) piezometer points along Jaalwala Distributary Canal Command Area (CCA) for measuring the water-table depths.

which the dimension of each cell was 200 by $200 \mathrm{~m}$. It has two layers in which the upper represents the unconfined aquifer whereas the bottom layer features the confined one. The depth of the unconfined aquifer coincides with the depth of blind pipes of each tube well while the bottom layer contains the filters or screens of them up to their entire length (Figure 3).

Ground surface elevation data was required as a representation of top of the model which was collected from the digital elevation model (DEM). Based on the topographic elevation acquired from the Global Mapper software elevation contours map was draw (Figure 4).

The model was calibrated by taking lateral permeability as $0.004 \mathrm{~m} /$ day whereas vertical permeability was taken as $0.0004 \mathrm{~m} /$ day which is equivalent to one tenth of the lateral permeability. These values fit in the observed and predicted water levels of the piezometers and are taken as such in the model. Total porosity and specific yields have been adjusted to 0.3 and 0.2 respectively. The area across the Eastern Sadiqia canal towards south Eastern and north Western corner have been treated as inactive zones since nothing is being contributed from 


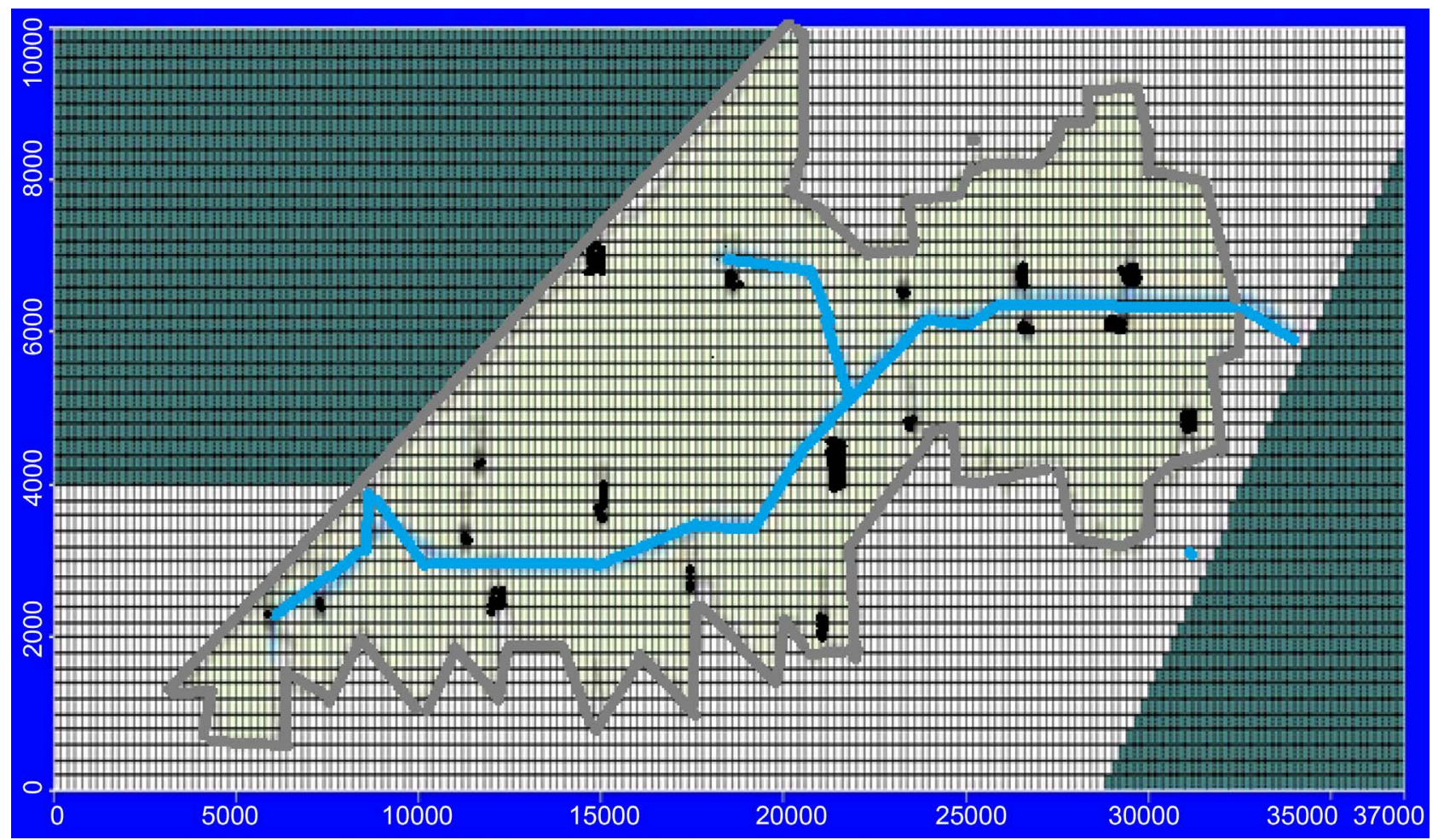

Figure 3. General layout of the model grid and its area.

these ends (Figure 5).

In order to calibrate the model in the light of observed and simulated water levels time series graphs at each piezometer were generated (Figure 3).

The inventory data of 535 tube wells covering well numbers, $\mathrm{X}$ - and Y-coordinates as regards model dimensions, top and bottom of the screens, status of wells whether active or otherwise, lengths and locations of blind pipes and filters, pumping schedule and well discharge in $\mathrm{m}^{3} /$ day have all been marked to the model (Figure 5 and Figure 6).

First simulation was run for 10 years and the second for 20 years under unlined and lined conditions respectively. Groundwater budget of the aquifer in and around the command of Jaalwala Distributary before and after lining was incorporated in the model to see a clear picture of the inflows and outflows of water within and outside this unconfined aquifer.

Average discharge capacity of Jaalwala Distributary within the study area throughout the year was 112 Cusecs. Losses from it have been estimated to be around six to seven percent of its discharge at its head which comes out to be 7.8 cusecs $(7 \%)$. The concentration of the canal water seeping into the aquifer has been calculated as $500 \mu \mathrm{S} / \mathrm{cm}$ which has been added to the model.

\section{Results and Discussion}

Results of Electrical Conductivity measurements of groundwater samples taken from 21 selected sites present near and at some distance from Jaalwala Distributary on biannual basis show that the groundwater present in the vicinity of the 


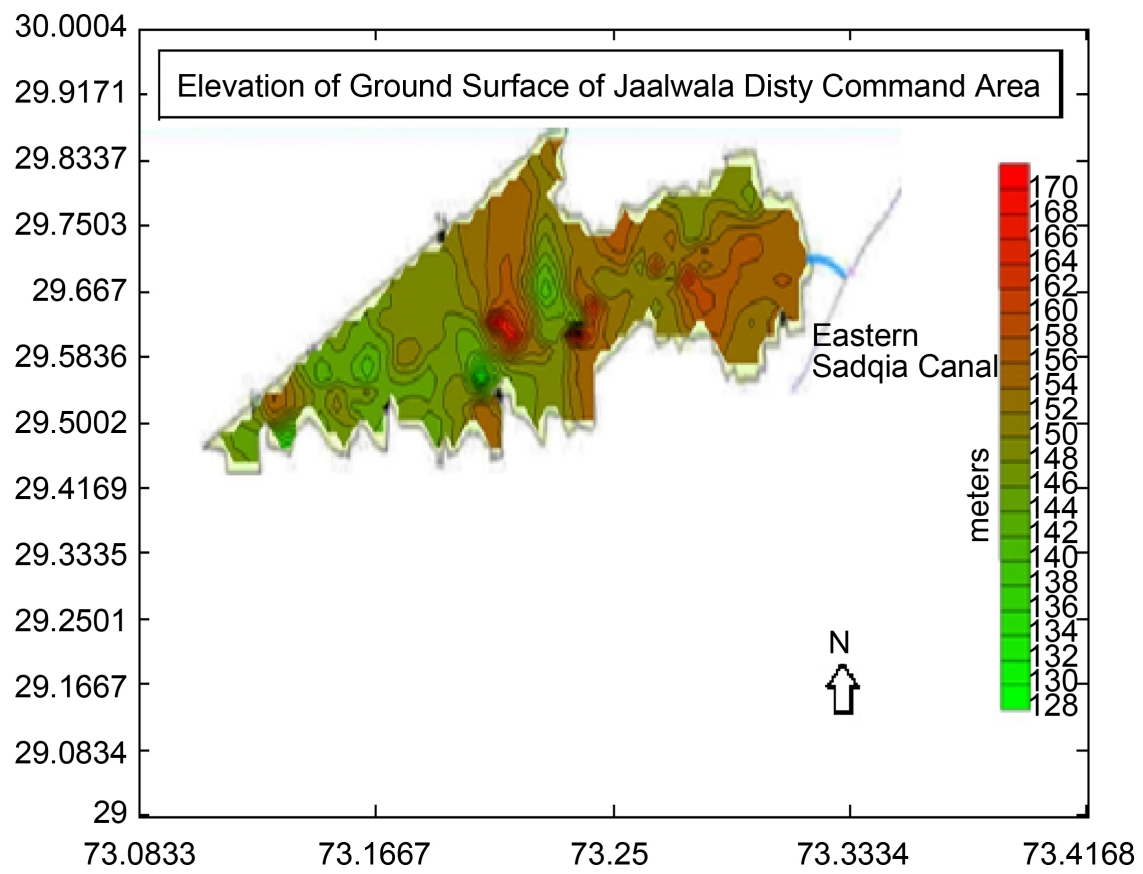

Figure 4. Topographic elevation contours map of jaalwala distributary.

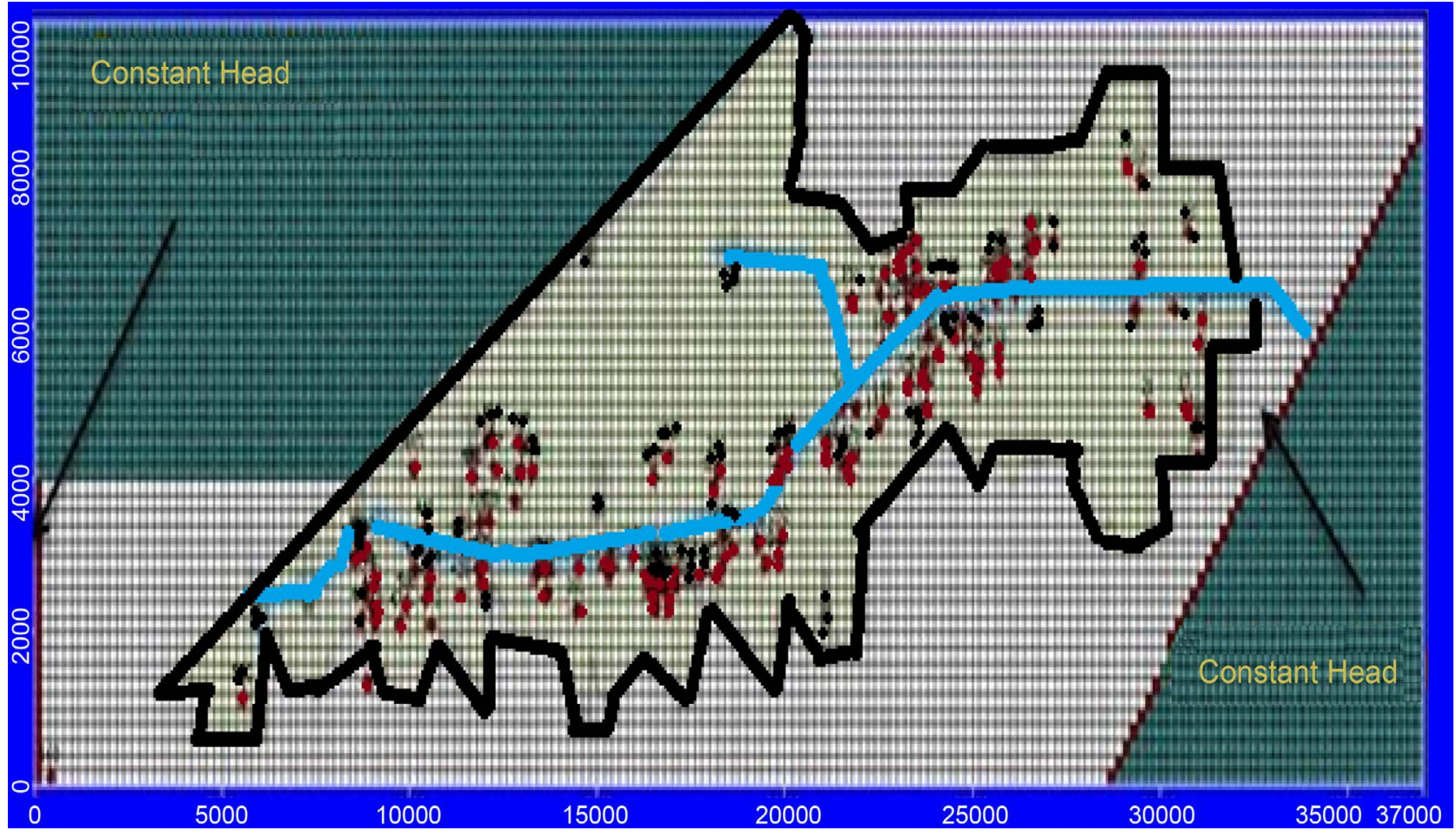

Figure 5. Boundary conditions of the study area as assumed in the model.

Distributary was mostly brackish though small pockets of fresh water are present along various sections where seepage is comparatively high. The quality of groundwater samples were recorded beneath those parts of this channel where there appears to be no seepage, very small outflow and over pumping show that water in these reaches is highly saline (Table 4). 


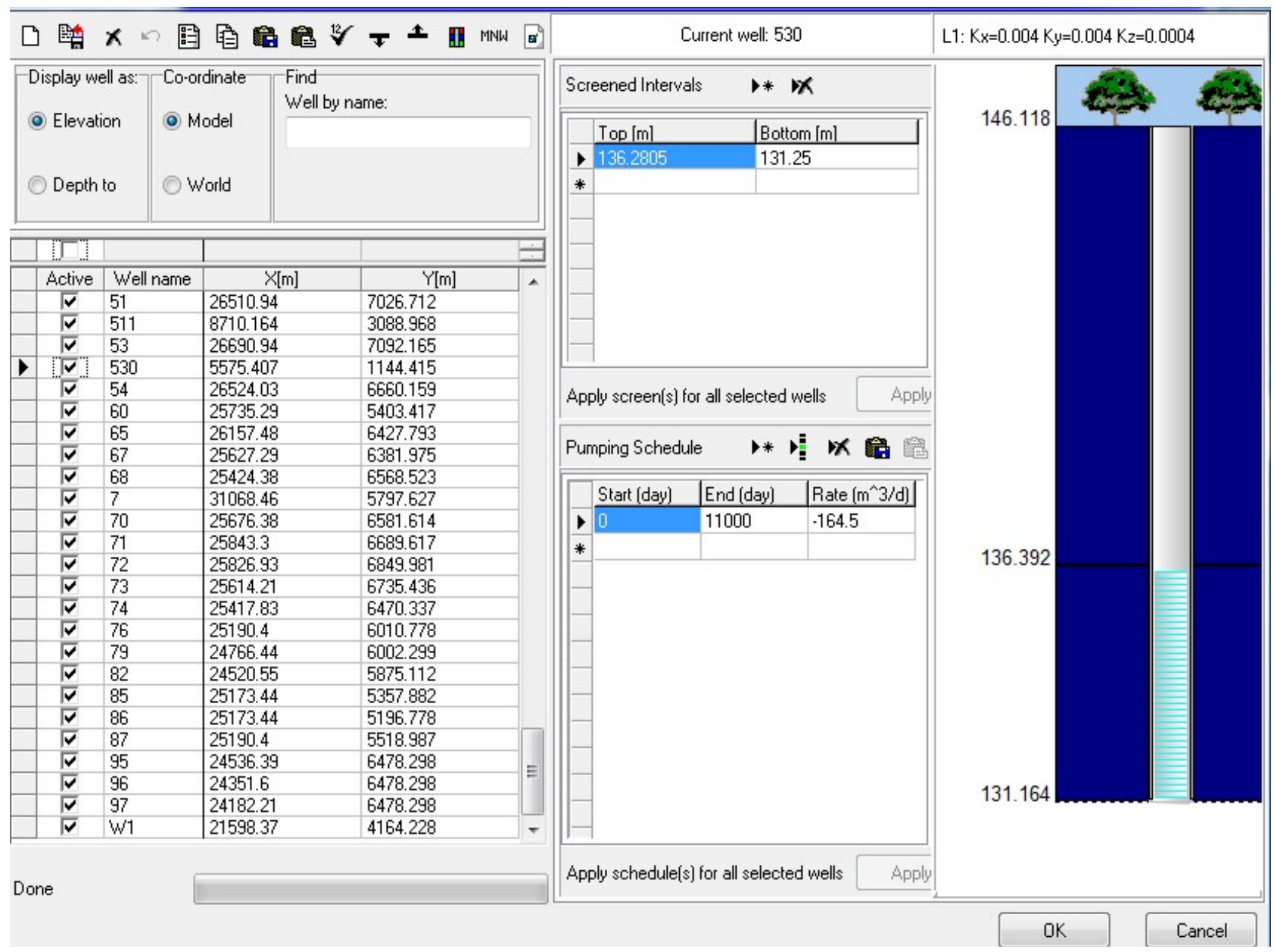

Figure 6. Tube well configurations showing their various components, pumping schedule and discharges.

The time-series graphs of predicted water levels was produced by the model 10 years before concrete lining and 20 years after it showed that water table after lining of Jaalwala Distributary declined from 1 to 9 feet depending upon the proximity of piezometers from the main Eastern Sadiqia Canal and the tube wells. Prediction regarding lowering of groundwater table was least near the Eastern Sadiqia Canal (unlined), minimum at the head potion of Jaalwala Distributary (still unlined), intermediate in its middle (lined since 2013) and maximum around the Tail section (Figure 7 and Table 5).

The groundwater quality data as observed from the sites closed to and away from Jaalwala Distributary show that seepage of fresh water from earthen sections of this canal keeps the below lying saline water zone at bay and maintains a thin layer of freshwater above it as is also depicted in the groundwater quality contours (Figure 8 and Table 6).

It can be seen that some tube wells were installed close to the Jaalwala Distributary in the tail section but their water quality is highly saline as seepage from this section has already been reduced as a result of lining in this reach since 2005. The results of electrical conductivity of sites 3 and 5 in the unlined upstream sections of the distributary (Head) was compared with sites 17 and 19 
Table 4. Electrical Conductivity variations recorded from 21 selected sites in the command of jaalwala distributary $(\mathrm{dS} / \mathrm{m})$.

\begin{tabular}{|c|c|c|c|c|c|c|c|c|c|c|}
\hline \multirow{2}{*}{$\begin{array}{l}\text { Sr. } \\
\text { No. }\end{array}$} & \multicolumn{3}{|c|}{$\begin{array}{c}\text { Water Quality Points (WQPs) } \\
\text { alongwith with Coordinates }\end{array}$} & \multirow{2}{*}{$\begin{array}{c}\text { EC } \\
\text { - Post } 09\end{array}$} & \multirow{2}{*}{$\begin{array}{c}\text { EC } \\
\text { Pre } 10\end{array}$} & \multirow{2}{*}{$\begin{array}{c}\text { EC } \\
\text { Post } 10\end{array}$} & \multirow{2}{*}{$\begin{array}{c}\text { EC } \\
\text { Pre } 11\end{array}$} & \multirow{2}{*}{$\begin{array}{c}\text { EC } \\
\text { Post } \\
11\end{array}$} & \multirow{2}{*}{$\begin{array}{c}\text { EC } \\
\text { Pre } 12\end{array}$} & \multirow{2}{*}{$\begin{array}{c}\text { EC } \\
\text { Post } 12\end{array}$} \\
\hline & Longitude & Latitude & WQPs & & & & & & & \\
\hline 1. & 73.390357 & 29.98815 & $11 / \mathrm{L}$ & 4.00 & 4.60 & 4.00 & 3.80 & 4.00 & 4.10 & 4.10 \\
\hline 2. & 73.388954 & 29.99855 & $10 / \mathrm{L}$ & 3.60 & 4.80 & 3.30 & 3.50 & 4.50 & 4.60 & 4.50 \\
\hline 3. & 73.391603 & 29.98295 & $8 / \mathrm{R}$ & 2.50 & 2.40 & 2.40 & 2.30 & 2.40 & 2.30 & 2.30 \\
\hline 4. & 73.391429 & 29.97402 & 9/R & 2.30 & 2.30 & 2.30 & 2.40 & 2.20 & 2.20 & 2.20 \\
\hline 5. & 73.352281 & 29.97452 & $14 / \mathrm{R}$ & 3.00 & 3.70 & 3.30 & 2.80 & 2.70 & 1.60 & 1.70 \\
\hline 6. & 73.314735 & 29.98651 & $15 / \mathrm{L}$ & 2.10 & 3.40 & 3.80 & 2.90 & 3.30 & 3.20 & 3.00 \\
\hline 7. & 73.299201 & 29.97661 & $19 / \mathrm{L}$ & 6.9 & 6.90 & 6.00 & 5.70 & 6.50 & 6.50 & 6.40 \\
\hline 8. & 73.299371 & 29.98159 & $20 / \mathrm{L}$ & 2.40 & 2.90 & 2.80 & 2.30 & 2.80 & 2.50 & 2.70 \\
\hline 9. & 73.299552 & 29.99707 & $16 / \mathrm{R}$ & 2.60 & 6.30 & 5.80 & 6.60 & 6.10 & 6.10 & 6.10 \\
\hline 10. & 73.299603 & 29.96156 & $17 / \mathrm{R}$ & 2.8 & 3.4 & 4.0 & 3.5 & 3.7 & 3.8 & 3.3 \\
\hline 11. & 73.299174 & 29.95304 & $18 / \mathrm{R}$ & 1.2 & 1.7 & 2.1 & 1.6 & 1.8 & 2.2 & 1.9 \\
\hline 12. & 73.286264 & 29.99409 & $22 / \mathrm{L}$ & 1.30 & 2.50 & 2.00 & 2.20 & 2.20 & 1.60 & 1.80 \\
\hline 13. & 73.287469 & 29.98505 & $21 / \mathrm{R}$ & 6.70 & 5.20 & 5.80 & 4.70 & 5.00 & 4.50 & 1.60 \\
\hline 14. & 73.258729 & 29.97171 & $25 / \mathrm{L}$ & 0.80 & 1.40 & 1.80 & 1.20 & 1.50 & 1.40 & 1.50 \\
\hline 15. & 73.259663 & 29.98515 & $23 / \mathrm{L}$ & 1.80 & 3.00 & 2.90 & 2.60 & 2.70 & 2.90 & 6.10 \\
\hline 16. & 73.244994 & 29.97421 & $26 / \mathrm{L}$ & 2.50 & 7.20 & 7.30 & 6.10 & 7.50 & 7.60 & 7.50 \\
\hline 17. & 73.217088 & 29.96942 & $27 / \mathrm{L}$ & 0.80 & 3.50 & 3.70 & 2.90 & 3.00 & 3.10 & 3.10 \\
\hline 18. & 73.195898 & 29.96062 & $29 / \mathrm{L}$ & 1.00 & 4.00 & 4.00 & 3.70 & 5.40 & 4.10 & 8.60 \\
\hline 19. & 73.195903 & 29.95353 & $30 / \mathrm{R}$ & 1.80 & 7.00 & 7.00 & 6.40 & 6.60 & 6.60 & 6.50 \\
\hline 20. & 73.195883 & 29.94909 & $31 / \mathrm{R}$ & N/A & 8.00 & 8.50 & 8.00 & 8.50 & 9.70 & 3.80 \\
\hline 21. & 73.142817 & 29.95138 & $32 / \mathrm{R}$ & 4.50 & 4.00 & 4.00 & 3.80 & 3.40 & 3.90 & 4.50 \\
\hline
\end{tabular}

located at the lined tail portion of Jaalwala Distributary (Table 7) which showed less variability in terms of electrical conductivity at sites 3 and 5 up to post-2012 because of constant seepage of freshwater from the unlined portion of the Distributary. On the other hand the electrical conductivity of sampling sites 17 and 19 near the tail portion of the distributary lined since 2005 showed quite a different trend. The groundwater quality of these samples during Pre-2009 was quite low which increased to $3000-7000 \mu \mathrm{S} / \mathrm{cm}$ because of non-replenishment of freshwater as a result of concrete lining of this section of the Distributary and consequent intrusion of saline water table in its place (Table 7 and Figure 9).

The model was run for a period of 30 years for developing a graph of conductivity versus time which includes a simulation. Actual electrical conductivity of 


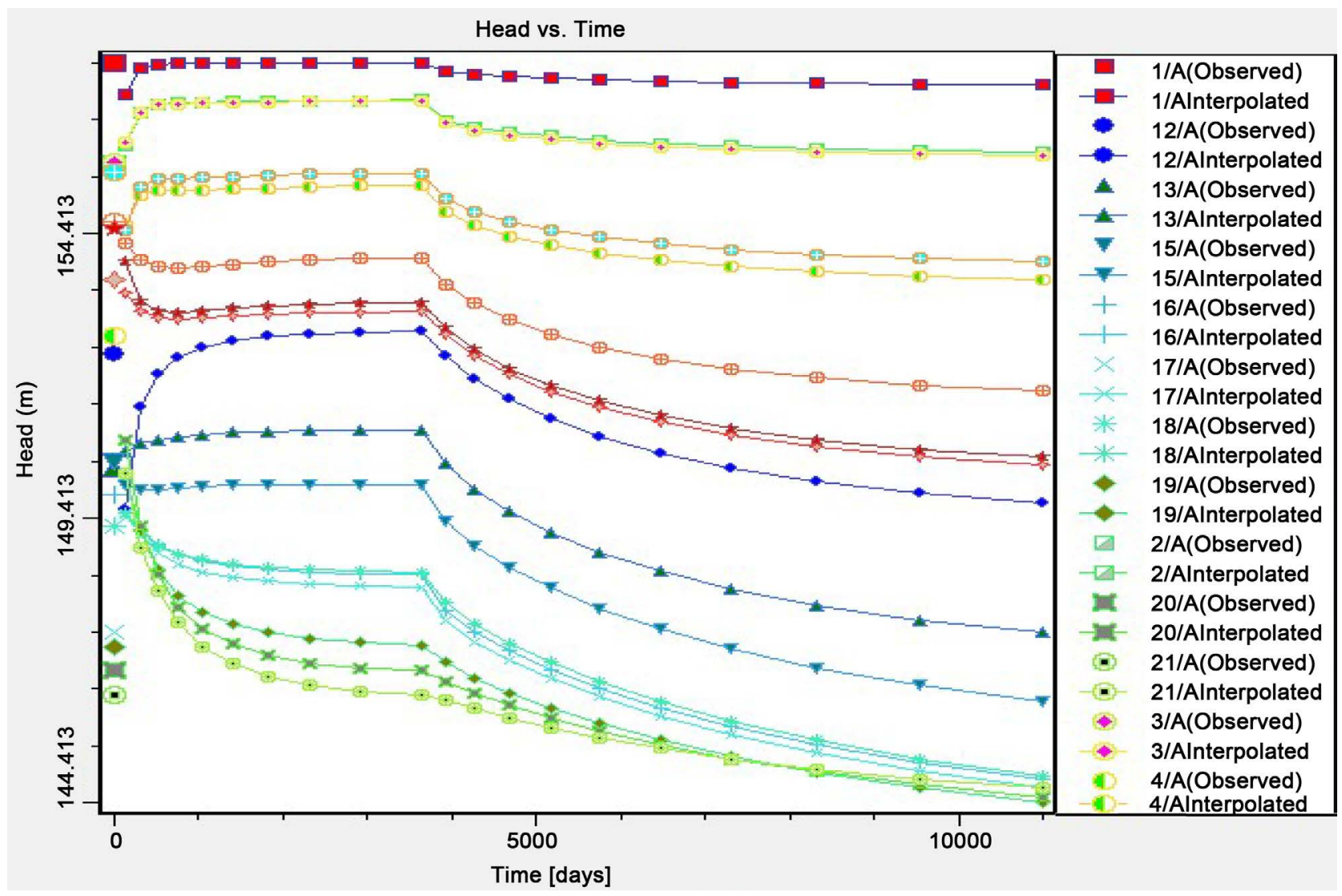

Figure 7. Predicted water levels in various piezometers before and after lining.

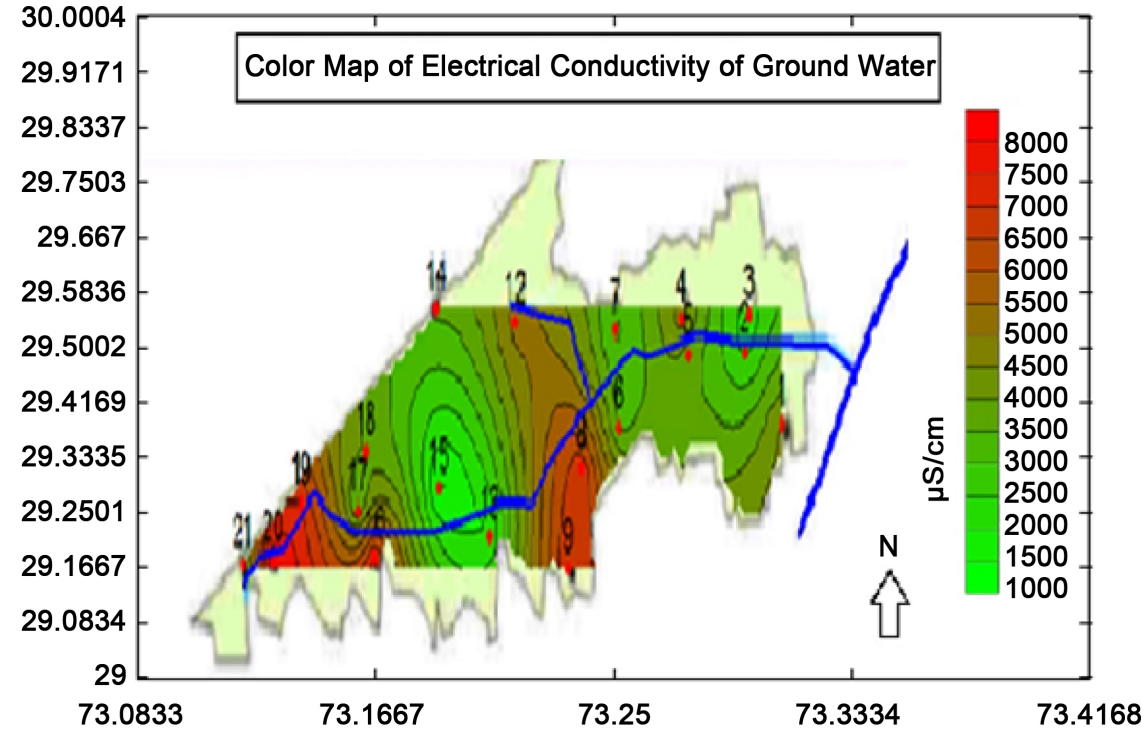

Figure 8. Groundwater quality contours as drawn with respect to actual readings of electrical conductivity for Post-Monsoon, $2009(\mu \mathrm{S} / \mathrm{cm})$.

groundwater just before lining at sampling sites No. 2, 3, 4, 12 and 16 was 2598, $887,1599,1210$ and $1307 \mu \mathrm{S} / \mathrm{cm}$ respectively which has been shown to increase gradually after lining and will approach the equilibrium value of $7000 \mu \mathrm{S} / \mathrm{cm}$ corresponding to the native groundwater salinity level of the area. Some short 
Table 5. Predicted decline in groundwater table by the Model after 20 years of lining (2028).

\begin{tabular}{|c|c|c|c|c|c|c|}
\hline \multicolumn{3}{|c|}{$\begin{array}{l}\text { Piezometer alongwith their } \\
\text { Coordinates }\end{array}$} & \multirow{2}{*}{$\begin{array}{c}\text { Actual water } \\
\text { levels just } \\
\text { before lining } \\
\\
\text { (In meters) }\end{array}$} & \multirow{2}{*}{$\begin{array}{c}\text { Predicted } \\
\text { decline in water } \\
\text { levels } 20 \text { years } \\
\text { after lining } \\
\text { (In meters) }\end{array}$} & \multicolumn{2}{|c|}{$\begin{array}{c}\text { Net Balance in } \\
\text { groundwater levels } \\
20 \text { years after lining }\end{array}$} \\
\hline $\begin{array}{l}\text { Piezometer } \\
\text { Nos. }\end{array}$ & Longitude & Latitude & & & (In meters) & (In feet) \\
\hline PPZ-06/L & 73.39445 & 29.98846 & 157.410 & 157.017 & 0.393 & 1.29 \\
\hline PPZ-04/R & 73.39479 & 29.97426 & 156.756 & 155.837 & 0.919 & 3.01 \\
\hline PPZ-08/R & 73.3634 & 29.97133 & 155.469 & 153.906 & 1.563 & 5.13 \\
\hline PPZ-07/L & 73.36335 & 29.98834 & 153.986 & 151.641 & 2.345 & 7.69 \\
\hline PPZ-10/L & 73.33153 & 29.98749 & 153.042 & 150.332 & 2.710 & 8.89 \\
\hline PPZ-14/L & 73.30148 & 29.98837 & 149.999 & 146.198 & 3.801 & 12.47 \\
\hline PPZ-15/L & 73.26827 & 29.98436 & 148.420 & 144.837 & 3.583 & 11.75 \\
\hline PPZ-20/L & 73.23511 & 29.96447 & 148.196 & 144.687 & 3.509 & 11.51 \\
\hline PPZ-21/R & 73.20993 & 29.94788 & 148.470 & 144.426 & 4.044 & 13.26 \\
\hline $\mathrm{PPZ}-22 / \mathrm{L}$ & 73.20104 & 29.96506 & 146.732 & 144.518 & 2.214 & 7.26 \\
\hline PPZ-24/L & 73.17312 & 29.96366 & 146.317 & 144.671 & 1.646 & 5.40 \\
\hline
\end{tabular}

Table 6. Actual water quality of tube wells located close to and at a distance from Jaalwala Distributary with respect to electrical conductivity $(\mu \mathrm{S} / \mathrm{cm})$ (Post-Monsoon, 2009).

\begin{tabular}{|c|c|c|c|}
\hline Sr. No. & Tube well Nos. & Close to Jaalwala Distributary & $\begin{array}{l}\text { At a distance from } \\
\text { Jaalwala Distributary }\end{array}$ \\
\hline 1. & 1 & - & 4100 \\
\hline 2. & 2 & 2300 & - \\
\hline 3. & 3 & 2200 & - \\
\hline 4. & 4 & 4600 & - \\
\hline 5. & 5 & 1600 & - \\
\hline 6. & 6 & - & 3200 \\
\hline 7. & 7 & 2500 & - \\
\hline 8. & 8 & - & 6500 \\
\hline 9. & 9 & - & 6100 \\
\hline 10. & 12 & - & 4500 \\
\hline 11. & 13 & 1600 & - \\
\hline 12 . & 14 & - & 2900 \\
\hline 13. & 15 & 1400 & - \\
\hline 14. & 16 & - & 7600 \\
\hline 15. & 17 & 3100 & - \\
\hline 16. & 18 & - & 4100 \\
\hline 17. & 19 & 6600 & - \\
\hline 18. & 20 & 9700 & - \\
\hline 19. & 21 & 3900 & - \\
\hline
\end{tabular}


Table 7. Electrical Conductivity of Samples taken from Sites No. 3 and 5 in the Head unlined portion and from Sites No. 17 and 19 in the Tail Lined portion $(\mu \mathrm{S} / \mathrm{cm})$.

\begin{tabular}{lcccccccccc}
\hline $\begin{array}{l}\text { Proposed Water Quality Points } \\
\text { (PWQs) along with Coordinates }\end{array}$ & \multicolumn{7}{c}{ Electrical Conductivity } \\
\hline Longitude & Latitude & PWQs & Post 09 & Pre 10 & Post 10 & Pre 11 & Post 11 & Pre 12 & Post 12 \\
\hline 73.388954 & 29.99855 & 3 & 2500 & 2400 & 2400 & 2300 & 2400 & 2300 & 2300 \\
73.352281 & 29.97452 & 5 & 3000 & 3700 & 3300 & 2800 & 2700 & 1600 & 1700 \\
73.217088 & 29.96942 & 17 & 800 & 3500 & 3700 & 2900 & 3000 & 3100 & 3100 \\
73.195903 & 29.95353 & 19 & 1800 & 7000 & 7000 & 6400 & 6600 & 6600 & 6500 \\
\hline
\end{tabular}

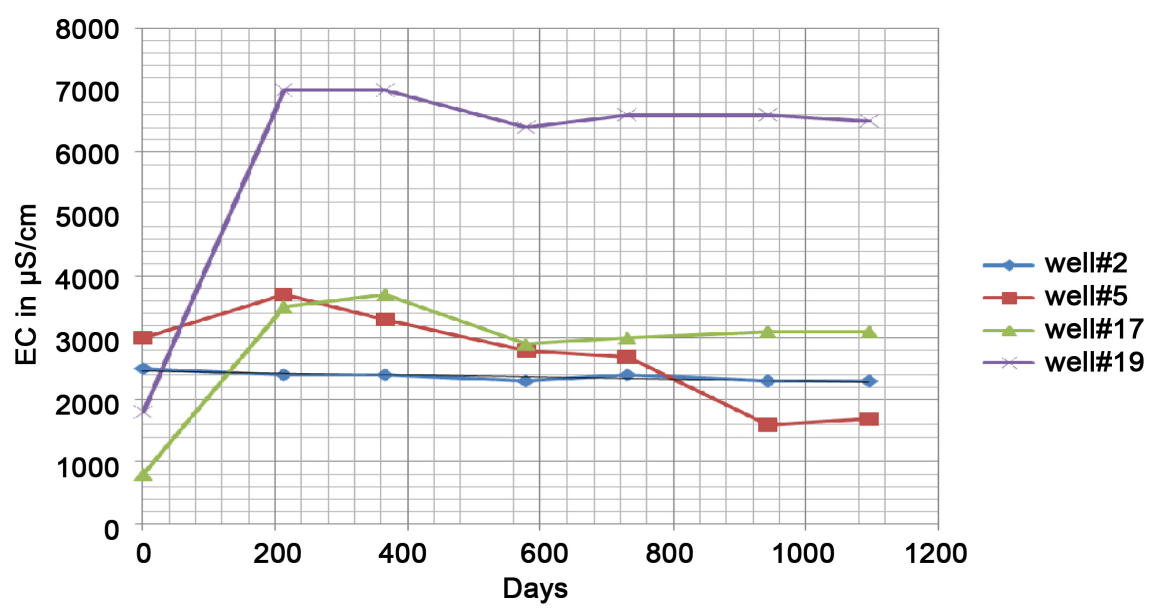

Figure 9. Electrical Conductivity variations in the unlined Head portion (at Sites No. 3 and 5) and the lined Tail Portion of Jaalwala Distributary (at Sites 17 and 19) $(\mu \mathrm{S} / \mathrm{cm}$ ) (Post 2009-Pre 2012).

term fluctuations in Electrical Conductivity after lining are expected at lined sites close to the Distributary because of depletion of freshwater pockets with time and filling their gap by the upcoming saline water table (Figure 10 and Table 8).

Samples taken from sites No. 5, 13 and 15 close to the Jaalwala Distributary and No. 9, 12 and 18 away from it (Table 6) with the purpose to analyze them chemically with respect to irrigation parameters were evaluated using Piper Diagram. Nearly ninety percent of ions present in a hydrologic system were $\mathrm{Na}^{+}, \mathrm{K}^{+}$, $\mathrm{Ca}^{2+}, \mathrm{Mg}^{2+}, \mathrm{SO}_{4}^{2-}, \mathrm{Cl}^{-}, \mathrm{HCO}_{3}^{-}$and $\mathrm{CO}_{3}^{2-}$. If $\mathrm{Na}^{+}$and $\mathrm{K}^{+}$were taken together as one type of positive ions and $\mathrm{HCO}_{3}^{-}$and $\mathrm{CO}_{3}^{2-}$ be assumed as similar negative ions, then top of the cations triangle will be taken by $\mathrm{Mg}^{2+}, \mathrm{Ca}^{2+}$ will be assigned the lower left while $\mathrm{Na}^{+}$and $\mathrm{K}^{+}$will collectively take its right corner. Similarly, $\mathrm{SO}_{4}^{2-}$ will be given the upper most turning of the anion triangle, $\mathrm{HCO}_{3}^{-}$and $\mathrm{CO}_{3}^{2-}$ together will take the lower left and the right corner of the base will be given to the $\mathrm{Cl}^{-}$ions. The Piper Diagram depicts that the basic constituents of the groundwater closed to distributary have low $\mathrm{Na}^{+}$contents while the sites located at some distance from the channel are high in $\mathrm{Na}^{+}$concentration. Thus it can be inferred that seepage of fresh water from the channel plays a prominent role in dilution of saline groundwater. This analysis also add weight 


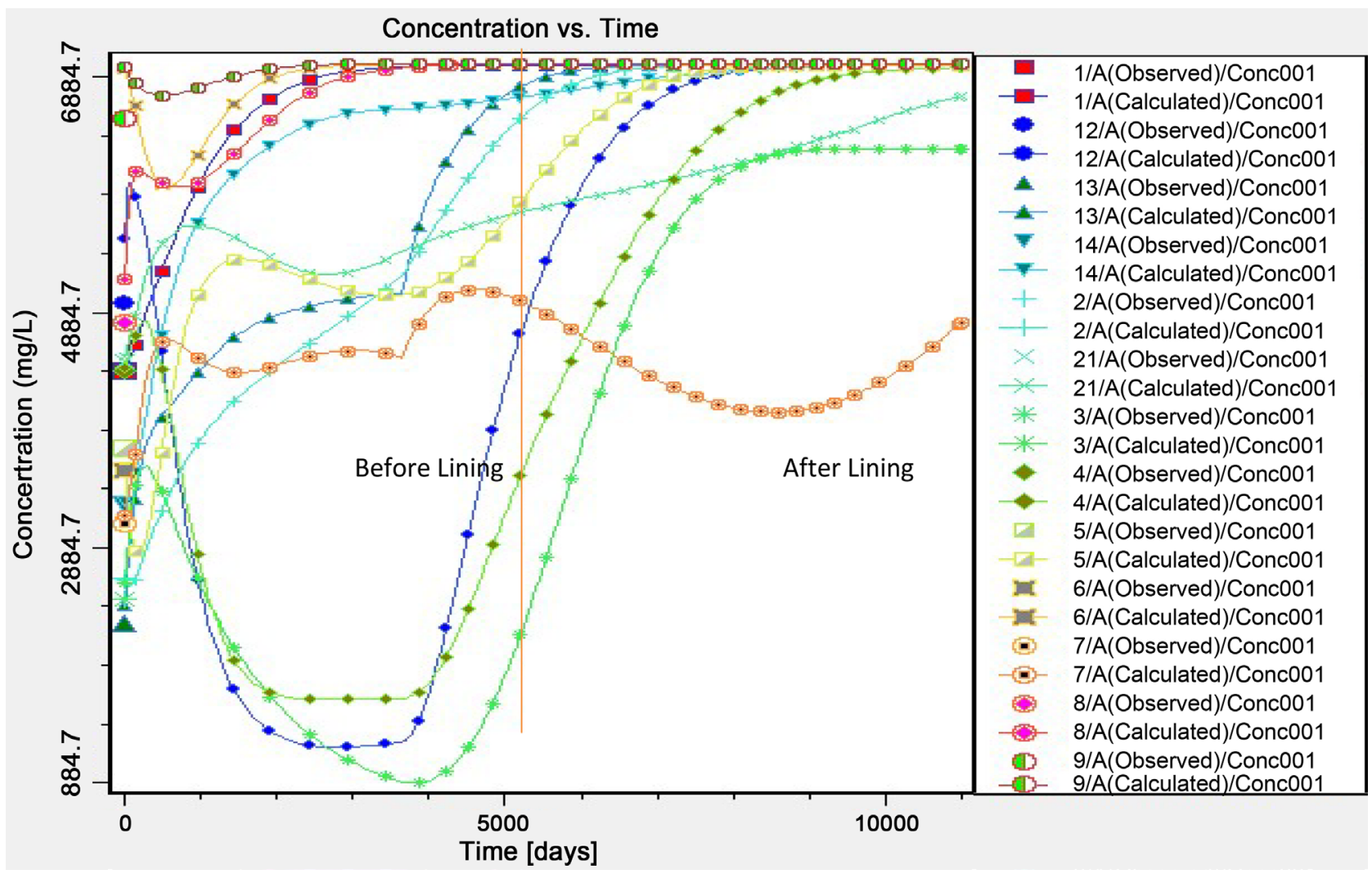

Figure 10. Simulated groundwater quality variations at Sites Nos. 2, 3, 4, 12 and 16 before and after Lining with respect to Electrical Conductivity $(\mu \mathrm{S} / \mathrm{cm})$ (Post 2009-Pre 2012).

Table 8. Predicted impact of lining on electrical conductivity variations by the model in 2009 and $2028(\mu \mathrm{S} / \mathrm{cm})$.

\begin{tabular}{ccc}
$\begin{array}{c}\text { Tube well } \\
\text { Nos. }\end{array}$ & $\begin{array}{c}\text { Recorded Electrical Conductivity just } \\
\text { before lining }\end{array}$ & $\begin{array}{c}\text { Predicted Electrical Conductivity 20 } \\
\text { years after lining }\end{array}$ \\
\hline 1 & 4382 & 6988 \\
2 & 2598 & 6994 \\
3 & 887 & 6269 \\
4 & 1599 & 6965 \\
5 & 5032 & 6994 \\
6 & 6990 & 6990 \\
7 & 4523 & 4788 (still rising) \\
9 & 6998 & 7000 \\
12 & 1210 & 6991 \\
13 & 5037 & 6997 \\
14 & 6610 & 6998 \\
15 & 4223 & 4244 \\
16 & 1307 & 6774 \\
17 & 4282 & 5087 \\
18 & 4845 & 6169 \\
\hline
\end{tabular}


to the argument that the seeped freshwater from the channels does not mix with the below lying saline water and retain its independent identity (Table 9).

Groundwater budget was computed by the model before and after lining of CCA of Jaalwala Distributary showed that inflows from Eastern Sadiqia Canal and from Jaalwala Distributary before concrete lining were 7.6 cusecs and 8.5 cusecs respectively. Outflows from the aquifer due to tube wells under unlined conditions was 15.1 cusecs and from the western boundary to downstream areas was 1.1 cusecs. Thus the seepage from Jaalwala Distributary going directly into the aquifer as predicted by the model was 8.5 cusecs which is equal to $7.6 \%$ of the discharge delivered at its head section [14] (Figure 11 and Table 9).

The model further predicted that Jaalwala Distributary will not further contribute any water to the below lying saline aquifer after its concrete lining. If the tube wells in the study area continue to run then inflow from Eastern Sadiqia Canal would increase from 7.6 cusecs (before lining) to 13.6 cusecs. Because of concrete lining of Jaalwala Distributary in the tail section, outflows from the western boundary will be reduced from 1.1 to 0 cusecs due to formation of a permanent structure in the way of seepage. A saving of 7.8 cusecs canal water

Table 9. Estimated seepage loss from the Irrigation canal system of punjab [14].

\begin{tabular}{cccc}
\hline Canal System & Kennedy & Benton & Blench \\
\hline Main Canals & 5 & - & 5 \\
Branches & 15 & 16.4 & 7 \\
Distributaries & 6 & 6.1 & 20 \\
Water Courses & 21 & 20.2 & 47.0 \\
Total & 47.0 & 42.7 & 45 \\
\hline
\end{tabular}

Water Budget Before and After Lining

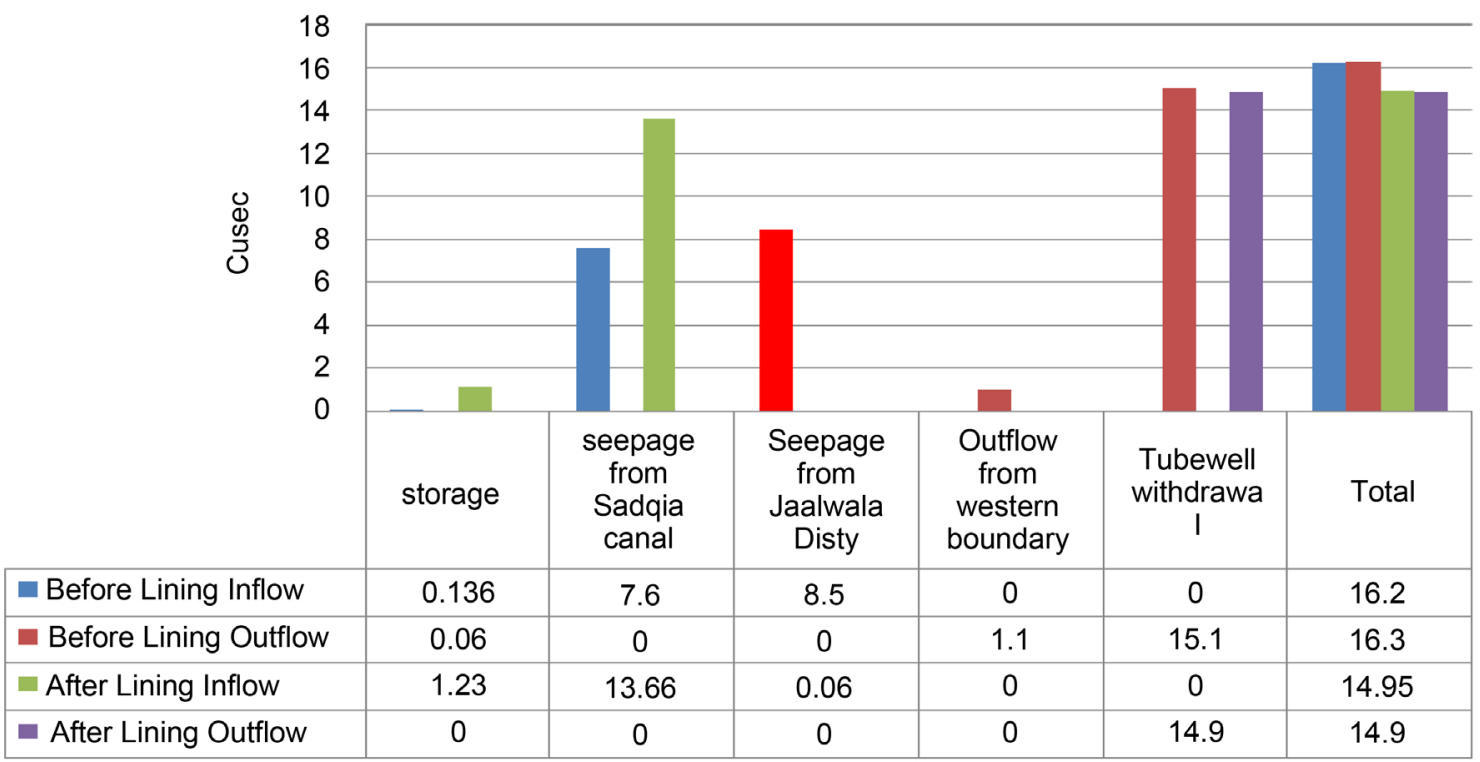

Figure 11. Groundwater Budget before and after lining of Jaalwala Distributary. 
has been predicted by the model which is equivalent to $7 \%$ of the total discharge of 112 cusecs delivered at the Head of Jaalwala Distributary. This calculation is in accordance with the experimental measurements of conveyance losses in other distributaries in Punjab (Table 9). The model has predicted that formation of a permanent concrete barrier in the way of seepage will minimize the recharge contribution to the underlying layer of good quality water present below the Jaalwala Distributary and will allow the saline water zone present around it to take its place. This situation will further aggravate when the presently installed 535 tube wells along the Jaalwala Distributary would be forced to pump degraded saline water to the farm fields thereby making the soil of the area nonproductive and barren on permanent basis.

The supposition that the farmers at the middle and tail sections of Jaalwala Distributary would get their allocated shares is practically a fiasco as a result of various practical and local reasons. After complete concrete lining of Jaalwala Distributary, the farmers would not be in a position to make conjunctive use of surface and groundwater for irrigating their fields as they would be left with the only option of using canal water which is often short at Middle and Tail.

Seepage tests as conducted by renowned engineers and scientists like Kennedy, Benton, Blench and Dyes in the Indus Plains from 1883 onwards have revealed that seepage losses from earthen main canals and their branches amount to $20 \%$, from distributaries and minors up to $6 \%$, from water-courses $10 \%$ and field losses to 10\% [9] (Table 9).

\section{Conclusion}

It was concluded that after lining Jaalwala Distributary, seepage losses amounting to 7.8 cusecs were likely to be saved and lower the water from 1 to 13 feet depending upon their distance from Eastern Sadiqia canal. Thus the positive impacts of lining were predicted by the model which accounts for a considerable savings with respect to seepage and lowers in groundwater table to an extent that the risk of secondary salinization can be evaded.

\section{Acknowledgements}

I would like to mention Muhammad Usman Saleem, Collage of Earth and Environmental Sciences University of the Punjab Lahore, Pakistan for the supervising and publication of this office report as research paper. My gratitude goes to Dr. Muhammad Akram, Hydrologist in Irrigation Department Punjab for sharing valuable data in this research. Special thanks for Open journal for applied sciences for giving a platform to publish this effort.

\section{References}

[1] Negenborn, R.R., Overloop, P.J., Keviczky, T. and De Schutter, B. (2009) Distributed Model Predictive Control of Irrigation Canals. Networks and Heterogeneous Media, 4, 359-380. https://doi.org/10.3934/nhm.2009.4.359

[2] Todd, D.K. and Mays, L.W. (2005) Groundwater Hydrology. 3rd Edition, John Wi- 
ley \& Sons Inc., Hoboken, 20-21, 590-592.

[3] Fetter, C.W. (2001) Applied Hydrogeology. 4th Edition, Prentice Hall, Upper Saddle River, $2,8$.

[4] Ashraf, M. (2009) Importance of Water: In the Light of Quran and Sunnat and Methodologies to Conserve It. Pakistan Council of Research in Water Resources (PCRWR), Islamabad, Pakistan, 1-38.

[5] The United Nations World Water Development Report (UNWWDR) (2003) Water for People Water for Life; The Natural Water Cycle. UNESCO, Barcelona, 65-67.

[6] Siddiqui, I.H. (1979) Irrigation Canals, Planning, Design, Construction \& Maintenance. National Book Foundation Pakistan, Lahore, 251-257.

[7] Awan, N.M. and Latif, M. (1982) Technical, Social and Economic Aspects of Water Resources Management in Salinity Control and Reclamation Project No. 1 (SCARP-1) in Pakistan. Centre of Excellence in Water Resources Engineering (CEWRE), Lahore, Pakistan, No. 22, 1-11.

[8] Burt, C.M. (2011) Canal Lining, Irrigation Training \& Research Center, Polytechnic State University California, USA, No. 6, 1-2.

[9] Ahmad, N. (1993) Water Resources of Pakistan and Their Utilization. Miraj Din Press, Urdu Bazar, Lahore, Pakistan, 15-31, 4B-1-4B-57.

[10] Ahmad, N. (1998) Drainage of Irrigated Lands of Pakistan. Shaf Printers, 1-R Green Park, Multan Road, Lahore, Pakistan, 5 B-41-5 B-49, 5 C-1-5 C-30.

[11] Javed, I., Hussain, S., Rehman, H. and Malik, A.S. (2014) Engineering Economics and Hydrology of Canal Lining: Evaluation of Canal Lining in Balloki and Sahiwal Canal Division of Lower Bari Doab Canal System. Water and Power Development Authority (WAPDA), Lahore, Pakistan, No. 301, 4, 6, 44.

[12] Asawa, G.L. (2008) Irrigation and Water Resources Engineering. New Age International, New Dehli, India, 211-219.

[13] Ahmad, N. (1979) Tubewell, Theory and Practice. Rippon Press, Lahore, Pakistan, $2.1-2.3$

[14] Ahmad, N. (1974) Groundwater Resources of Pakistan. Rippon Press, Lahore, Pakistan, 246-249.

[15] Kahlown, M.A., Tahir, M.A. and Rasheed, H. (2005) Water Quality Profile in Pakistan, 2005 (Third Report 2003-2004). Pakistan Council of Research in Water Resources (PCRWR), Islamabad, Pakistan, 3-7.

[16] Alam, S.M., Ansari, R. and Khan, M.A. (2000) Water Crisis in Pakistan Agriculture. How to Manage Scientifically? Pakistan \& Gulf Economist, No. 27, 29-38.

[17] Department of Sustainability, Environment, Water, Population and Communities (DSEWP\&C), Australia (2012) Salinity and Water Quality. Australia, 1-3.

[18] Pakistan Institute of Legislative Development and Transparency (PILDAT) (2003) Lahore. 11-21.

[19] Lautz, L. and Siegel, D. (2006) Modeling Surface and Ground Water Mixing in the Hyporheic Zone using MODFLOW and MT3D. Advances in Water Resources, 29, 1618-1633. https://doi.org/10.1016/j.advwatres.2005.12.003 
Submit or recommend next manuscript to SCIRP and we will provide best service for you:

Accepting pre-submission inquiries through Email, Facebook, LinkedIn, Twitter, etc. A wide selection of journals (inclusive of 9 subjects, more than 200 journals)

Providing 24-hour high-quality service

User-friendly online submission system

Fair and swift peer-review system

Efficient typesetting and proofreading procedure

Display of the result of downloads and visits, as well as the number of cited articles Maximum dissemination of your research work

Submit your manuscript at: http://papersubmission.scirp.org/

Or contact ojapps@scirp.org 